
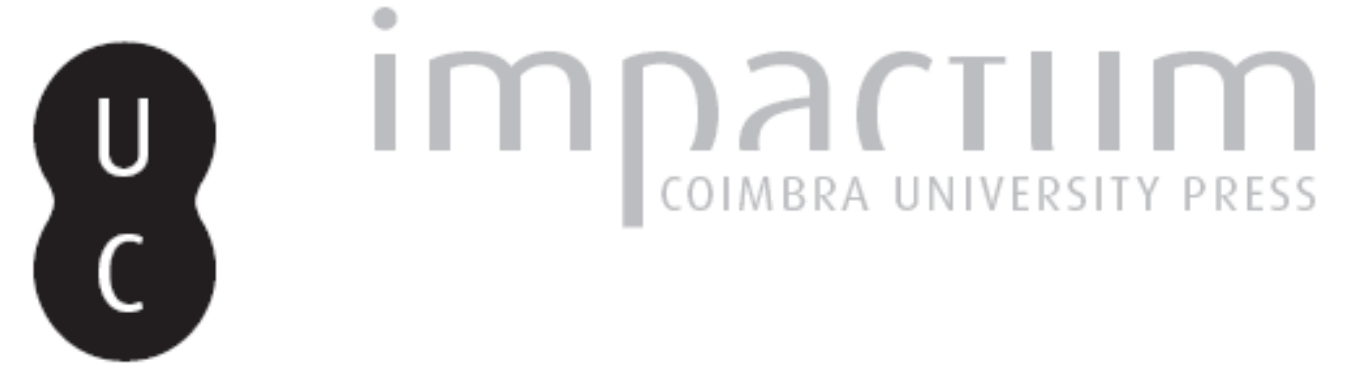

\title{
Bayer promotional activities in the Czechoslovak Republic and the Republic of Lithuania in 1918-1940
}

Autor(es): Vranová, Vilma; Gudiene, Vilma; Rusek, Václav

Publicado por: Imprensa da Universidade de Coimbra

URL persistente:

URI:http://hdl.handle.net/10316.2/36776

DOI:

DOI:http://dx.doi.org/10.14195/1647-8622_12_13

Accessed : $\quad$ 26-Apr-2023 02:14:43

A navegação consulta e descarregamento dos títulos inseridos nas Bibliotecas Digitais UC Digitalis, UC Pombalina e UC Impactum, pressupõem a aceitação plena e sem reservas dos Termos e Condições de Uso destas Bibliotecas Digitais, disponíveis em https://digitalis.uc.pt/pt-pt/termos.

Conforme exposto nos referidos Termos e Condições de Uso, o descarregamento de títulos de acesso restrito requer uma licença válida de autorização devendo o utilizador aceder ao(s) documento(s) a partir de um endereço de IP da instituição detentora da supramencionada licença.

Ao utilizador é apenas permitido o descarregamento para uso pessoal, pelo que o emprego do(s) título(s) descarregado(s) para outro fim, designadamente comercial, carece de autorização do respetivo autor ou editor da obra.

Na medida em que todas as obras da UC Digitalis se encontram protegidas pelo Código do Direito de Autor e Direitos Conexos e demais legislação aplicável, toda a cópia, parcial ou total, deste documento, nos casos em que é legalmente admitida, deverá conter ou fazer-se acompanhar por este aviso.

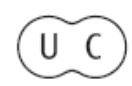


histórias da saúde

ESTUD OSD O SÉCULO

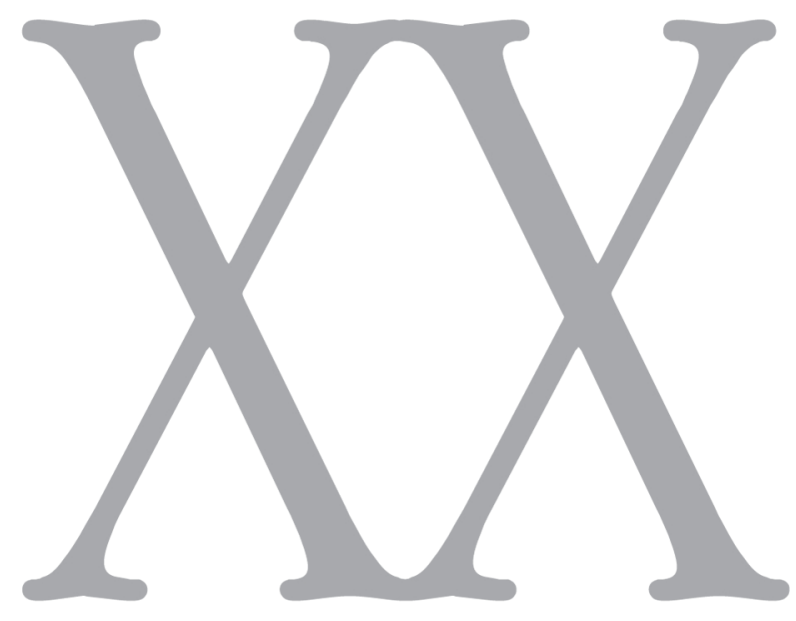

número 12 • 2012

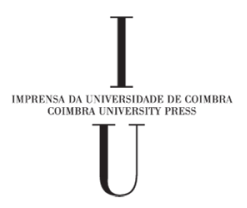




\title{
Bayer promotional activities in the Czechoslovak Republic and the Republic of Lithuania in $1918-1940$
}

\author{
Vilma Vranová \\ Vilma Gudiene \\ Václav Rusek
}


Vilma Vranová, Doutora e Professora da Faculty of Pharmacy in Brno, University of Veterinary and Pharmaceutical Sciences Brno, República Checa. E-mail: vranavi@ seznam.cz

Vilma Gudiene, Lithuanian Museum of the History of Medicine and Pharmacy of Lithuanian University of Health Sciences, Kaunas, Lituania

Václav Rusek, Czech Pharmaceutical Museum in Kuks, República Checa. 


\section{Introduction}

The success of a company depends not only on product quality but also on salesmanship. The important part of salesmanship is advertising. In the 20th century drug manufacturers paid considerable attention for drug promotional campaigns. They developed memorable trademarks, established promotional departments, prepared international and original advertising campaigns.

The pharmaceutical industry is today a global enterprise, but there were large international pharmaceutical companies at the beginning of the 20th century too. One of the biggest pharmaceutical companies was Bayer, part of I.G.Farben. This company had branch offices all over Europe and North and South Americas, its remedy promotion was unified. In this article Bayer`s advertising campaigns in two countries - the Czechoslovak Republic and the Lithuanian Republic in the years 1918 - 1940 are reviewed. German drug companies were the biggest importers in both countries. Bayer was one of the largest exporters of medicines at that time.

The archives and materials of funds of the Czech Pharmaceutical Museum in Kuks in the Czech Republic and Lithuanian museum of the History of Medicine and Pharmacy in Kaunas were researched. These museums house lots of Bayer's samples: leaflets sent by post and given out by medical representatives, trade journals, trade catalogues, gift items to doctors (e.g. calendars) and to pharmacies (e.g. barometer-thermometer, diaries), letters to doctors and pharmacists and other materials.

Professional print materials for pharmacists and physicians and lay media were another source. Bayer regularly published medicine advertisements in the professional print media of both countries and even in the lay press in Czechoslovakia.

\section{Bayer}

The company "Friedr. Bayer et comp." was founded on August 1, 1863 by dye salesman Friedrich Bayer (1825-1880) and master dyer Johann Friedrich Weskott (1821-1876). The company manufactured and sold synthetic dyestuffs. Between 1881 and 1913, Bayer developed into a chemical company with international operations. Dyestuffs remained the company's largest division but there were new fields of business too. The most important for Bayer's continuing development was the establishment of a major research capability by Carl Duisberg (1861-1935). Bayer was transformed into a joint stock company called "Farbenfabriken vorm. Friedr. Bayer \& Co." in 1881.

Bayer's research efforts gave rise to numerous intermediates, dyes and pharmaceuticals, including Aspirin", called the "drug of the century", that was developed by Felix Hoffmann and launched onto the market in 1899.

The creation of a worldwide sales organization was the most important factor in the company's development. Bayer had sold dyestuffs to many countries in its early years. By 1913, over 80 percent of income came from exports. Before World War I, the company had branch offices in Russia, France, Belgium, the United Kingdom and the United States. Bayer's development was interrupted by World War I. The effects of the war were devastating. The company lost most of its foreign assets and the export markets. Sales in 1919 amounted to 
only two thirds of the 1913 figure, inflation exhausted Bayer's financial reserves. There were a few important chemical companies in Germany; the biggest were Bayer, BASF and Agfa. In 1925 the president of Bayer, Carl Duisberg, initiated a merger of the major German chemical companies into a single entity known as the Interessen Gemeinschaft Farbenwerke, or I.G. Farben. Leverkusen became the headquarters for the I.G.'s pharmaceutical sales association, and the Bayer Cross was used as the trademark for all of the I.G.'s pharmaceutical products.

Bayer was the biggest pharmaceutical company in inter-war years; it has its branch offices and representations all over the world. In 1937 comp. Bayer had 93 branch offices in all continents including New Zealand or Japan. Fig.1

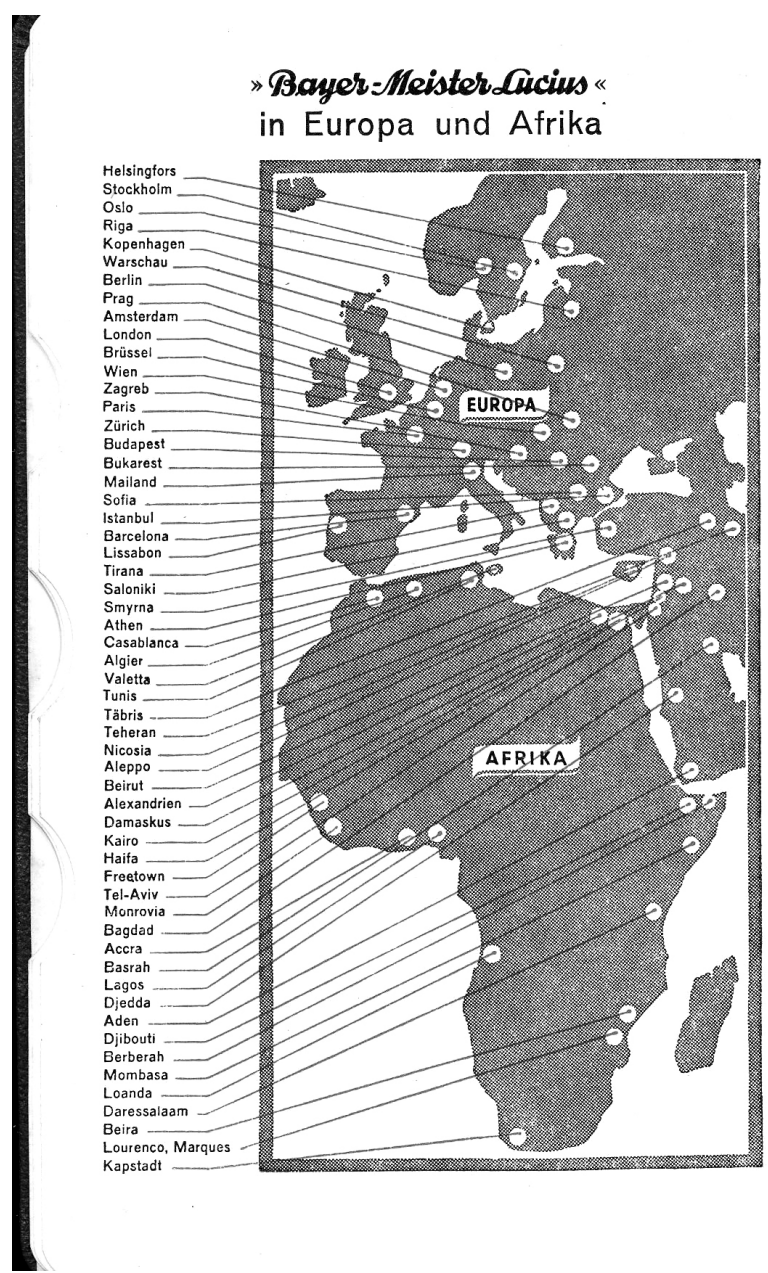

Fig. 1. Bayer Arzjahrbuch 1932. 
The pharmaceutical market and industry of Czechoslovakia and Lithuania

The Czechoslovak Republic

Czechoslovakia was established on October 28, 1918 as one of the successor states of the Austro-Hungarian Empire at the end of World War I and as part of the Treaty of Versailles. It consisted of the present day territories of the Czech Republic, Slovakia and Carpathian Ruthenia. Newborn Czechoslovakia included some of the most industrialized regions, e.g. Bohemia and Moravia, of the former Austria-Hungary. Its independence and integrity existed only until World War II when Czechoslovakia was invaded by Nazi Germany and divided into the Protectorate of Bohemia and Moravia and the puppet Slovak State. German occupation ended on 9 May 1945 and the Czechoslovak Republic was re-established.

Pharmaceuticals and remedies were prepared by about 300 producers in interwar Czechoslovakia. Most of them were based in Prague and North Bohemia. The biggest producers were Fragner (Dolní Měcholupy in Prague,1930), Hell (Komárov in Opava, 1883), Medica (Smíchov in Prague, 1908), Norgine (Ústí nad Labem, 1909), Heisler (Chrást u Chrudimi, 1910), Chemical company in Bohumín with saccharine manufacture, (Bohumín, 1917), Remed (Karlín in Prague, 1919), Radiumchema (Kolín, 1927), Interpharma (Modřany in Prague, 1932).

The size of the drug market in Czechoslovakia in 1937 was about 300 million CZK. The share between remedies prepared according to prescriptions and proprietary medicines was about $1: 1$, about 30 percent of patented drugs were prepared in pharmacies, the rest in pharmaceutical companies.

At the beginning of the thirties about 60 percent of patented drugs were imported from abroad - mostly from German manufacturers (70 percent), Switzerland (12 percent) and France ( 9 percent). The number of imported drugs began to fall with growth of the Czech pharmaceutical industry. In 1931, the share of imported medicines constituted 70 million CZK, and in 1935 - 27 million CZK. ${ }^{1,2}$

The production and sales of patented drugs were regulated by Government Regulation No. 26/1926 Coll. on manufacture of proprietary medicine. This regulation set also rules for remedy advertising and included promotional materials in authorized items. ${ }^{3}$

There were 2102 patented drugs registered in 1937. ${ }^{4-9}$

The number of pharmacies increased - there were about 800 pharmacies in 1918 and about 1000 in 1938. The population of Czechoslovakia was 10 million, so at that time it made 11 to 12 thousand inhabitants per one pharmacy. ${ }^{1,2}$

As stated above, the Company Bayer belonged to the biggest importers. Bayer authorized 88 proprietary drugs until 1931 (meantime called I.G.Farben); in 1937 they marketed 150 drugs, i.e. about 7 percent of registered medicines. Novocainsuprarenin inj. reg. no. 261, the first registered medicine, was registered on 27 October1923, Bayer's best known remedy - Aspirin was registered on 18 January 1927, No. 29, decision No. 32.213/26. ${ }^{4-9}$ According to the law from 1883 (Regulation of the Imperial \& Royal Ministry of the Interior and Trade No. 152/1883.r.z., which regulates the rights of pharmacies in relation to trading in chemicals and other materials and similar 
businesses) pharmacies were allowed to exclusively market prescription medicines. A new office of "submitter" - a person responsible for submitting drug registration applications - who had to be a pharmacist, an owner or a provisor of a pharmacy was established. This registration submitter managed remedy registration - even registration of remedies from pharmaceutical companies - and was responsible for its quality. Bayer`s registration submitter used to be, in 70 per cent of cases, the owner or the provisor of Adam pharmacy in Prague. After German occupation, German pharmacists Ph. Mr. Dr. K. Zieger and Ph. Mr. Dr. Fr. Prögler became Bayer`s registration submitter. ${ }^{4-10}$

As the exclusive representation of the Czechoslovak Republic was selected the Company "Pharma” Sperk\&Prochaska, farm. př́ípravky „Bayer“, Praha.

The company was established by two partners, Jan Prochaska $\left({ }^{*} 1855\right.$, Kazňov) and Vilem Sperk $(* 1860$, Prague). The fields of their operation were business agency and factorage with pharmaceutical products and also toxins, in case their distribution and sales were not designated to pharmacies. The company was founded on September 1, 1925, its first residence was in Hybernska street 40. The company dealt with collecting of orders and delivering to other plants. After four years of operation two new partners joined the company, Karel Prochaska and Hugo Herrmann become partners of the company on May 23,1930, two months later, on June 9,1930, Pharma Sperk`s founders Vilém Sperk and Karl Prochaska left the company. Despite this fact the company kept its original name.

The company continued with its activities even in The Protectorate of Bohemia and Moravia during World War II. The Company Bayer took complete control of the Pharma Sperk Prochaska company which was therefore renamed on December 9, 1940. The new name was Pharma "Bayer "Grobel \& comp. Under the leadership of Josef Grobel, Otto Lukesch and Walter Ernst Adolf Mayer-Berge Pharma „Bayer "Grobel \& comp, the company operated during World War II. Fig.2 The company was nationalized in 1948 and became part of the Sanitas national company. ${ }^{12}$

\section{The Republic of Lithuania}

The situation in the Republic of Lithuania was - as a result of many decades under Tsarist Russia occupation - different. The Vilnius University which was founded in 1579 and played a distinguished role in training of pharmacists and establishing a scientific foundation for the profession was closed down by the order of Tsar Nicholas I in 1832. The Medical-Surgery Faculty was reorganized into Medical-Surgery Academy and closed in 1842 too. Pharmacists were not being prepared in Lithuania. Gradually Lithuania became only a distant province of the Russian Empire.

The Republic of Lithuania was established on 16 February 1918. Lithuania was invaded and annexed by the Soviet Union (USSR on August 3) in 1940, when the Soviet Union formally annexed Lithuania, declaring it to be the fourteenth republic of the USSR. From 1941 to 1944, it was occupied by German troops. In 1944, the Soviets again annexed Lithuania. Lithuania declared independence on 11 March 1990.

When Lithuania declared its independence in 1918 medicine and chemical laboratories worked only in the town of Vilnius and its district. In 1919, Poland assumed control of Vilnius and the Capital was transferred to Kaunas. 


\section{P H A R M A - "Bayer " \\ GROBEL \& CO.}

ALLEINVERTRETUNG FOR BOHMEN UND MAHREN DER "Bayer" I. G. FARBENINDUSTRIE AKTIENGESELLSCHAFT LEVERKUSEN

An das

Kreisgerdicht in Handelssachen Abtl.VII

P r a II,

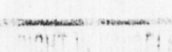

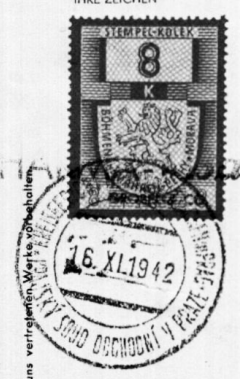

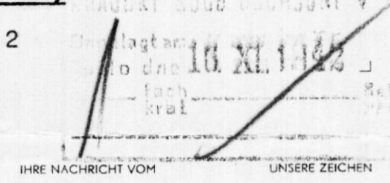

$\mathrm{Kn}$.

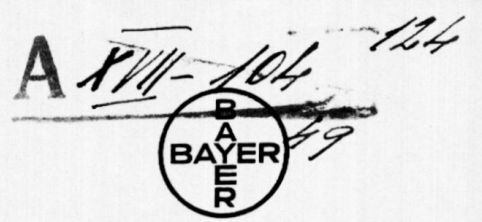

POSTANSCHRIFT: PHARMA - Bayer ", PRAG I,

FERNRUF: $\quad 613.55$

GESCHXFTSZEIT: 1. 4. BIS 30. 9.: MONT. BIS FREITAG 7.30-16 UHR SONNABEND ... 7.30-12.30 UHR
1.10. BIS 31. 3.: MONT. BIS FREITAG 8-16.30 UHR MONT. BIS FREITAG 8-16.30 UHR
SONNABEND $\ldots . . .18-13$ UHR

BANKKONTO: BOHMISCHE UNION.BANK, PRAG
BERLINERSTRAS

VERKA UFS - A B TEIL U N G

PRAG, DEN 12. November 1942.

Betr.:Anschriftenänderungen unserer Gesellschafter. creas

Wir bitten zur Kenntnis zu nehmen, dass unsere im Handelsregeister Abt.A Band XVII Seite 104 eingetragenen Firma ihren Sitz in Prag I,Berlinerstrasse 2l, hat und die Anschriften der Gesellschafter nunmehr wir folgt lauten:

Walther Ernst Adolf Meyer-Berge,Prag XIX, Seydlitzstr.2 Dr.rer.nat.0tto Lukesch, Prag IV, Benedikt-Rieth-Strasse 1. :Te Phammar Bayer "Qrobel \& a 西

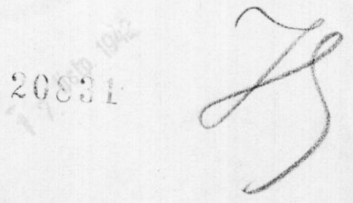

Fig. 2. Dossier A XVII-104; box N. ${ }^{o} 1278$, Státni oblastni archiv Praha (State Regional Archive in Prague) 
The first drug manufacturing companies were established in 1921-1922 ("Vaistija" and Chemical \& Pharmaceutical Laboratory "Sanitas" in Kaunas, "Galen” in Šiauliai) but in 1938 there were already registered eleven chemical and pharmaceutical laboratories in Lithuania: "Pharmakon" (Klaipeda, 1925), "Lithfarma", "Vaistas" (Kaunas, 1935), "GerMaPo", "Central Public Drug Wholesaler" (Kaunas, 1928) and other. ${ }^{13}$

The size of the drug market in Independent Lithuania (1918-1940) ranged from 8 million Lt. to 10 million Lt. The share between remedies prepared according to prescriptions and proprietary medicines was about $1: 1$, about one third of patented drugs were prepared in pharmacies, another third in pharmaceutical chemistry labs, and the rest was imported from abroad - mostly from German manufacturers.

In 1937, the share of imported medicines constituted 1.6 million Lt., and in $1939-2.23$ million Lt. ${ }^{14}$

Merck, Riedel, Schering, Bayer, and Knoll were the German companies mostly advertising their production which indicates that their products comparised the major part of imported drugs.

Enterprises that wanted to sell their products in Lithuania had to present to the governing institution - the Department of Health by the Lithuanian Ministry of the Interior - drug samples, descriptions and three publications in medical press evaluating the efficiency of any drug intended for marketing. Drug samples were transferred to the analytical laboratory, and subsequently - to the institute of pharmacy for their content evaluation. Foreign enterprises had representatives or agents who took care of these procedures.

The number of pharmacies was around 300-350 in interwar Lithuania. The population was 2,5 million, so at that time it made 7,5 to 8 thousand inhabitants per one pharmacy.

Since 1926, regulation of drug imports in Lithuania became more stringent. That year, "The list of patented medicines allowed for importing into Lithuania, approved by the Council of Medicine" was published for the first time. This list contained 650 entries;

37 medications allowed for importing were produced by Bayer, 31 - by Merck, 27 - by Boehringer, and 19 - by Schering. ${ }^{15}$

In 1928, this list was supplemented with 685 entries, 89 medications being produced by Bayer. This list of medications allowed for importing was expanded on a continuous basis. ${ }^{16}$

Pharmaceutical manufacturers, including Bayer, did not focus on the individual market in Lithuania and worked with the three Baltic states - Lithuania, Latvia and Estonia. Two branch offices of the company Bayer in Kaunas were mentioned - Otto Wittkopp, Kaunas, Jorgen Buch \& Co., Kaunas, but no data about their activity were found. ${ }^{17}$

Meanwhile, Bayer's branch office Baltpharma in Riga (Latvia) was operating both actively and effectively. This subdivision represented Bayer in the three Baltic countries - Lithuania, Latvia, and Estonia. It published advertising editions in German, placed advertisements in local languages in the professional print media, sent promotion information to Lithuanian pharmacists and physicians, and took care of drug registration. At first, the branch office was established in Riga, in Pferde Street, and later on it moved to Kungu Street Fig. 3. We did not find the establishment date of this branch office, but from 1926 it led a creative advertising campaign of Bayer medications. 
Senden Sie mir kosten los Muster und Literatur nachstehend genannter Präparate d. l. G. FARBENINDUSTRIE AKTIENGESELLSCHAFT Pharmazeutische Abteilung "Bayer-Mloterduciw" Leverkusen a/Rh.

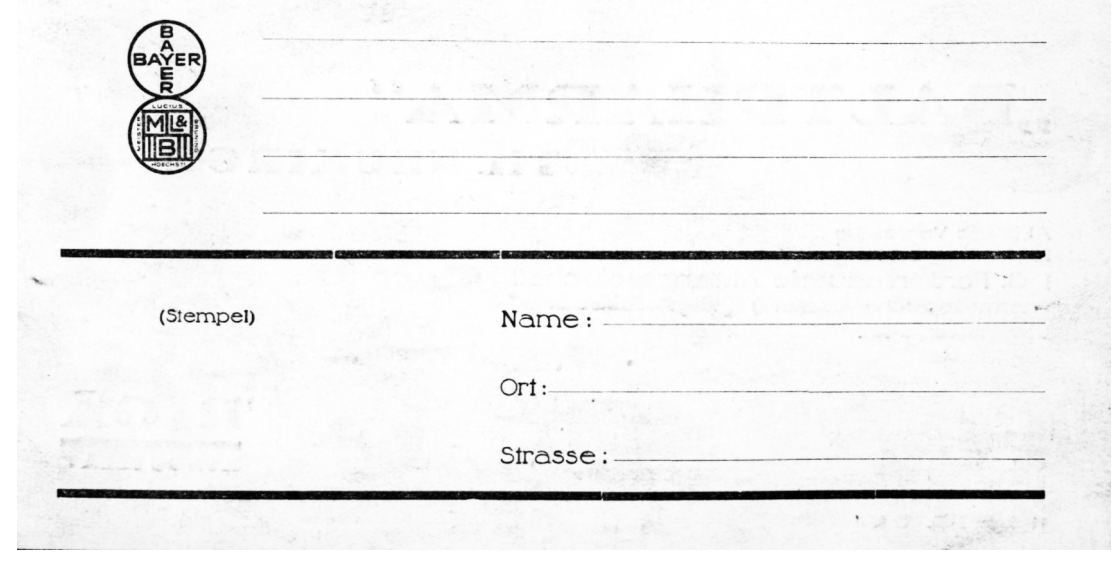

Fig. 3. Postcard, about 1930 .

\section{Advertising}

Advertising was always an inseparable part of any trade, pharmaceutical trade not excluding. Trade and manufacture of remedies were always strictly regulated and remedy adverts had also many limitations.

\section{Czechoslovakia}

The manufacture and sales of patented drugs were regulated by Government Regulation No. 26/1926 Coll. on manufacture of proprietary medicine. This regulation set also rules for remedy advertising and included promotional materials in authorized items. Manufacturers who wanted to sell their products had to present to the Ministry of Public Health and Physical Education not only their drug samples, descriptions of remedies, information about pricing etc. but also all promotional materials. Advertising was allowed without limitation until 1938 when promotion of prescription medicines was restricted to professional press only.

\section{Lithuania}

The Lithuanian Ministry of the Interior published the first document that set rules for medicine imports in 1927. The Department of Health was responsible for giving permissions and licenses to import medicines. Manufacturers who wanted to 
sell their products had to present to The Department of Health three drug samples in original package, descriptions of remedies and three reviews from a head of some Lithuanian hospital. In that review he indicated that a particular medicine had been tested in his hospital, had been of a good healing quality and based on that he could then recommend granting permission for import of a new drug.

All imports of medicines that were analogous to domestic products were forbidden. ${ }^{18}$

This document was republished a year later. New rules were confirmed in 1928. The requirement to ask hospital directors for reviews was changed. From 1928 manufacturers who wanted to sell their products had to present to the Department of Health three articles (from different authors) about a particular medicine. The new rules also allowed to import medicines that were analogous to domestic medicines. ${ }^{19}$

Public style of adverts

There were a few possibilities of remedy advertising targeted at public, including press advertisements. Another ways of remedy promotion were posters and leaflets shown in pharmacies and window displays.

Press adverts

Publishing of drug advertisements in the lay press was forbidden in Lithuania, except for cases with special permissions issued by the Department of Health.

Adverts aimed at public were published in the daily press, journals and especially in women magazines (e.g. Žena a domov - Woman and Home, Rozkvět - Blossom) Fig. 4 or almanacs in Czechoslovakia. All those possibilities of drug promotion were restricted in 1938 when advertising of prescription medicines was limited to professional press only.

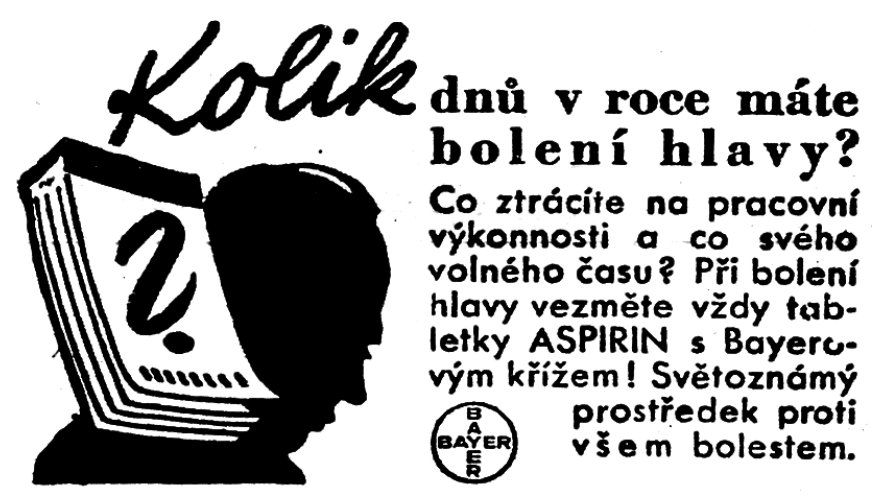

Fig. 4. Rozkvět [Blossom], 1939. 


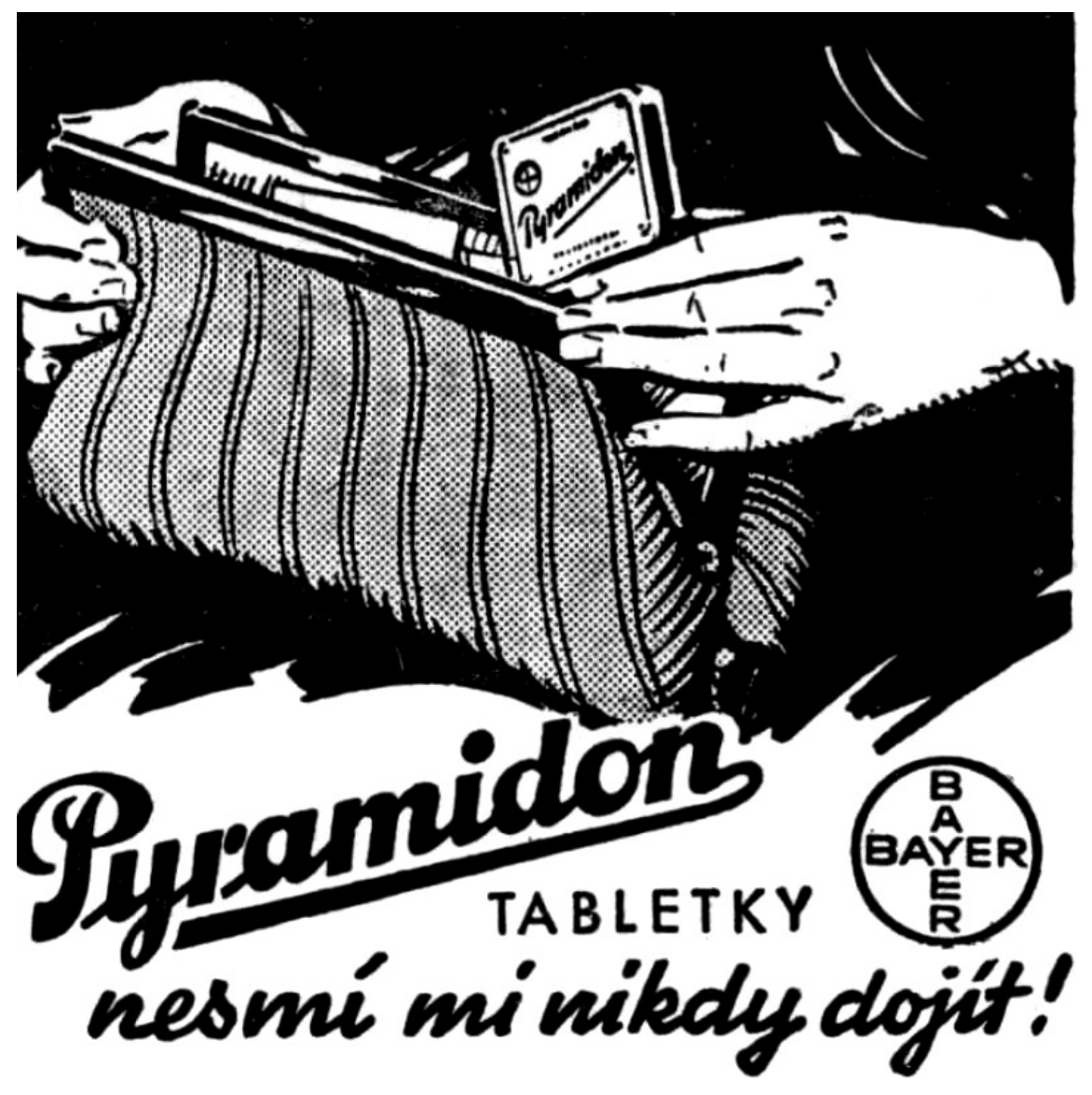

Tak prohlašuje každá zkušená žena, která vyzkoušela tohoto osvědčeného pomocníka $v$ bolesti při nevolnostech kritických dnü.

T a ż t e s e l ék a r e ! 


\section{Professional type of adverts}

Promotional activities targeted at professionals, practitioners and pharmacists were more varied in both countries. Those included mainly professional press insertions in medical or pharmaceutical journals.

The main journal for physicians in Lithuania was the "Medicina" ("The Medicine") (1920-1944), and for pharmacists - the "Farmacijos žinios" ("The Pharmacy News") (1923-1940). The majority of Bayer's advertisements were published in the journal "Medicina". The first advertisement by this company in the "Medicina" was published in $1929 .^{20}$

In this issue, Bayer (Farbendustrie) advertised remedy Casbis with Bismuth as an ingredient. The first advertisement in the journal "Farmacijos žinios" ("The Pharmacy News") was issued in 1936.

Within three years (1936-1939) 10 different "Bayer" advertisements appeared in the journal.

The last "Bayer" advertisement shows the company`s worldwide operations. ${ }^{22}$ Fig. 1

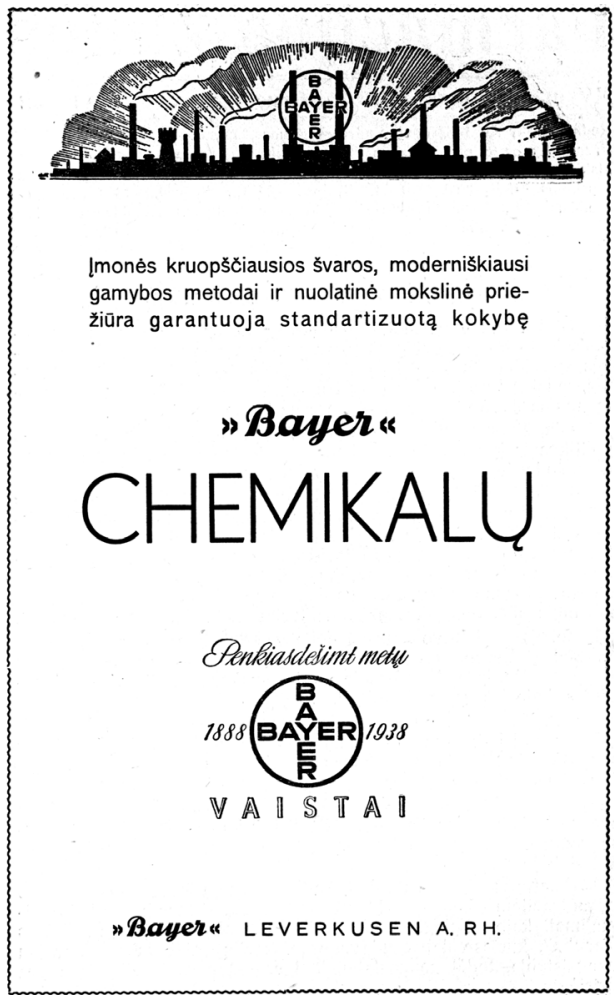

Fig. 5. Bayer Cross, Farmacijos žinios, 1938. 
There were several medical or pharmaceutical journals in Czechoslovakia (Časopis lékařů českých - Journal of Czech Physicians (1862 - up to now), Praktický lékař General Practitioner (1921 - 1950), Časopis československého lékárnictví - Journal of Czechoslovak Pharmacists (1882 -1950), Lékárnický týdenník - Pharmaceutical Weekly (1919-1924), Praktický lékárník - General Pharmacist (1932-1941). All these journals published advertisements of pharmaceutical companies. We could also find drug adverts in almanacs and year-books.

Bayer's remedy promotion was characterized by its originality and a large variety. Their adverts e.g. depicted buildings of a pharmaceutical factory, its equipment, test-tubes used for research and portrayed a chemist dressed in a white smock ${ }^{23}$, the strengths of one of the company's plants are highlighted in the text: "State-of-the-art methods of thorough cleanliness and constant scientific observation guarantee the standardized quality of pharmaceutical chemicals" ${ }^{24}$.

A factory with two chimneys with the Bayer Cross on them is used as a common motive. Fig. 5
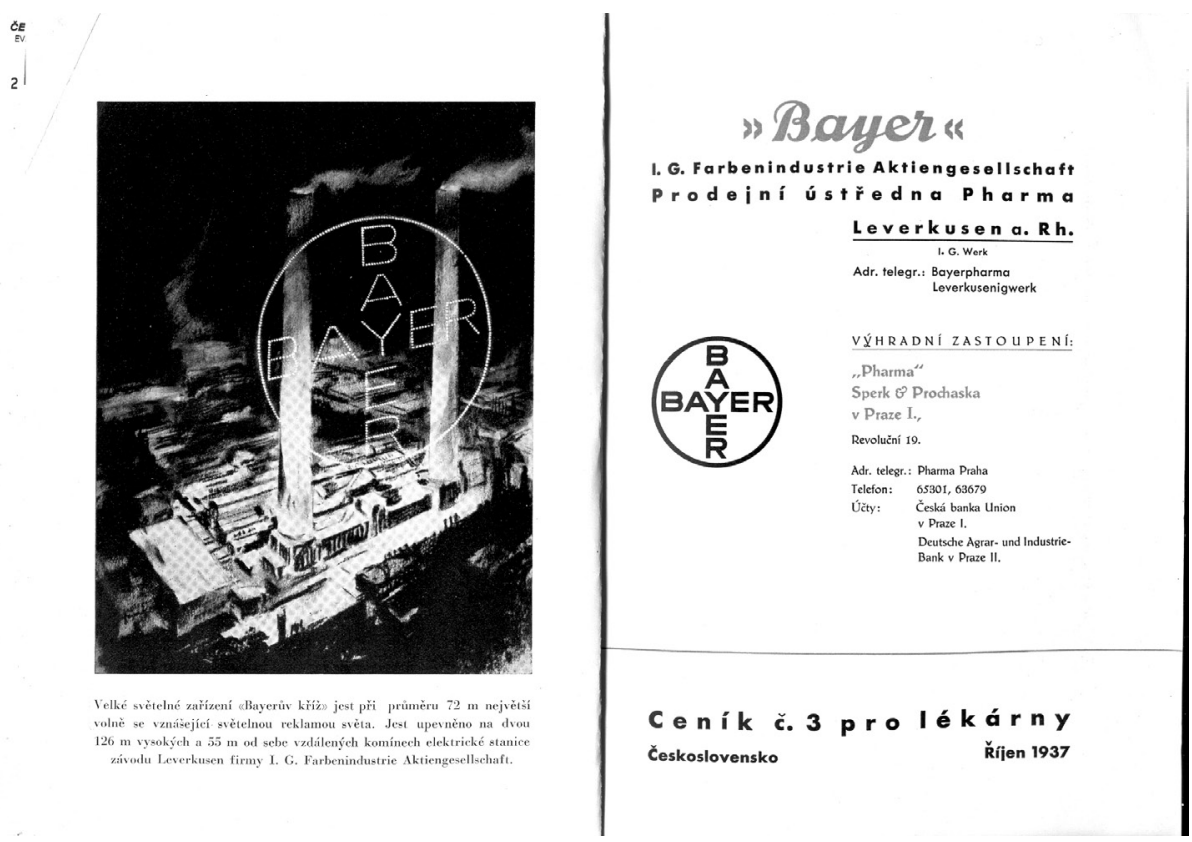

Fig.5. Bayer Cross, Price list, 1937. 


\section{TERAPEUTICKÉ ZPRÁVY

\begin{tabular}{l|ll}
\hline \hline 1938 & PRAHA & ČISLO 2 \\
\hline
\end{tabular}

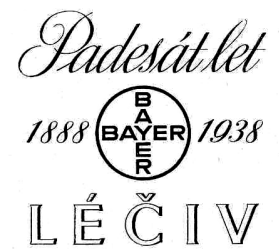

Rokem 1938 uplyne 50 let od té doby, kdy roku 1888 se rozhodlo veden tehdejš́ch $\gg$ Farbenfabriken vorm. Friedrich »BAYER \& \& Co.\& v Elberfeldu vybudovati vedle výroby barviv vlastní farmaceutické oddělení, což časově souhlasilo s počátkem moderní synthesy léčiv, $\mathrm{k}$ jejímuž dalšímu významnému rozvoji \&AYER\& od počàtku značně přispíval.

Se stoupající řadou poznatkủ $v$ nejrưznějších oborech vědy šiřil se tếž v příští době stále více okruh zájmủ a činnosti našich vědeckých laboratoří, jejichž práce $\mathrm{v}$ dalším období byla silně podnícena tím, že př̀i spojení jednotlivých závodů v jednotnou I. G. Farbenindustrie Aktiengesellschaft Leverkusen se stal \#BAYER\& sídlem centrály farmaceutického od̉dĕlení.

Tím mohly býti značně podpořeny výsledky badání, dosažené pracemi našich výzkumných ústavú v Elberfeldu, Hoechstu a Marburgu, které se týkaly všech oborů lékařstvi a epočívaly na pokud možno nejužší spolupráci chemicko-farmaceutické vědy a techniky $\mathrm{s}$ experimentálním a klinickým lékařstvím. Výsledky těchto praci našich vědeckých laboratoři vedly $\mathrm{k}$ velké řadě hodnotných, všeobecně urnávaných př́pravkú a založily pověst jejich výtečné jakosti, která je dnes vyjádřena v celém světě ve standardovaném pojmu lečiv »BAYER*. Vymožeností, jichž se dosáhlo $v$ terapii během uplynulých 50 let, nebylo by dosaženo bez nejužší, pro badání nezbytné spolupráce $\mathrm{s}$ praktickým lékařstvím, za kterou na tomto místě co nejsrdečněji děkujeme všem pánủm lékařủm. Pr̛̀i vytváření vztahũ, které spojuji farmaceutické oddělení »BAYER* na podklađě jeho obsáhlé organisace s lékaři všech zemi, mají význačný podil naše »Terapeutické zprávy

Vyjadřujeme proto $\mathrm{v}$ tomto jubilejním roce zvlášt svou naději, že naše domáci sdělení vyplní $\mathrm{i} v$ budouenu svủj dûležitý úkol a přispéjí $\mathrm{k}$ dalšímu nrohloubení této spolupráce.

Fig. 6. Bayer's Anniversary.

Great attention was paid to presentation of Bayer's $50^{\text {th }}$ anniversary. Fig.6

Some advertisements portrayed the company by illustrating its power or even a chemist at work in a research laboratory. Historical motives were widely used as well Fig.7, Advertisement ideas were mostly created by Bayer's advertising department in Germany. Sometimes we can find the same pictures appearing both in Czechoslovakia and Lithuania. Fig. 8

\section{Direct marketing, sampling}

The company Bayer sent booklets, books, trade catalogues and calendars containing descriptions of Bayer's medicines, their application and characteristics to general practitioners and pharmacists. These catalogues and calendars had a uniform appearance and similar content. The Czechoslovakian editions were issued in Czech and German. The Company Bayer published trade journal Terapeutické zprávy/Therapeutischen Berichte (1929-1941) in the Czechoslovak Republic. 


\section{Pharmazeutische Chemikalien "Bayer *}

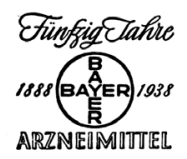

"Bayer"

Leverkusen a. Rh.

Fig. 6. Bayer's Anniversary.

Terapeutické zprávy/Therapeutischen Berichte were based on the corporate journal Pharmazeutische Berichte.Fig. 5 The content of the Czech edition compiled translated articles from the German edition and either scientific or amusing articles of Czech opinion leaders, case reports, and of course a lot of adverts. This journal was distributed among practitioners for free. The journal was published both in Czech and German.

The Lithuanian situation was more complicated. Lithuania was a small country whose population numbers were below 3 million. Pharmaceutical manufacturers, including Bayer, worked with the three Baltic States - Lithuania, Latvia and Estonia. The Company Bayer established its office for these three Baltic States in their geographical centre - Riga (Latvia) which took care of the entire Baltic region. Bayer's information materials were not translated into local languages: Lithuanian, Estonian and Latvian, the company used to publish materials in German. Letters to doctors and pharmacist were written in the Lithuanian language, advertisements in the Lithuanian press were in Lithuanian too. Other information books and calendars were in German. 


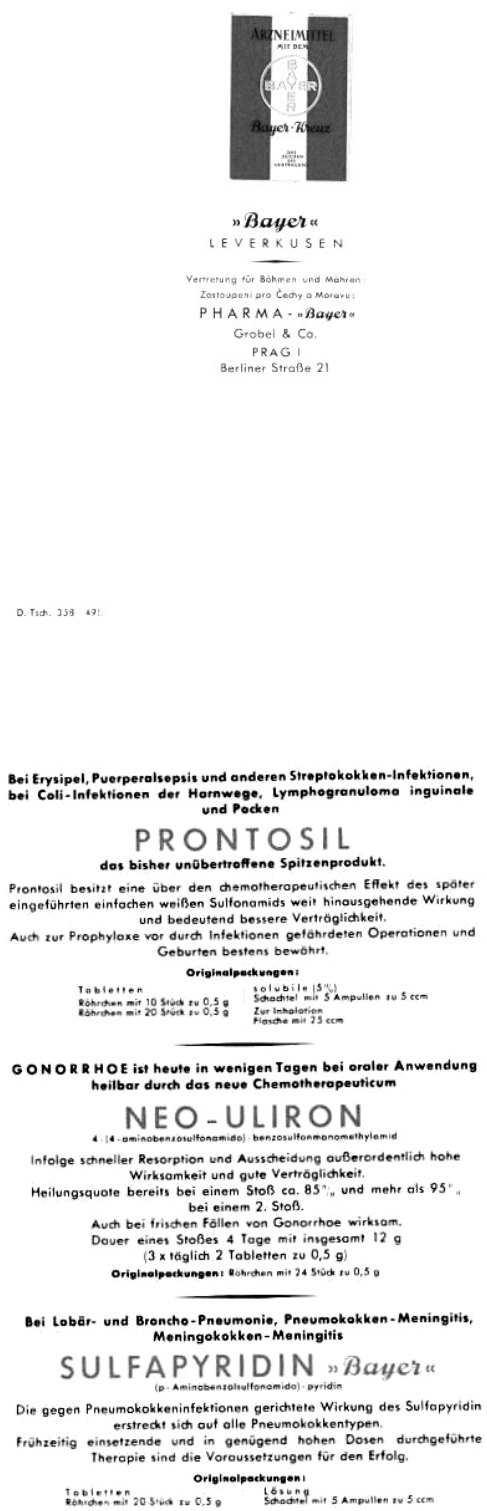

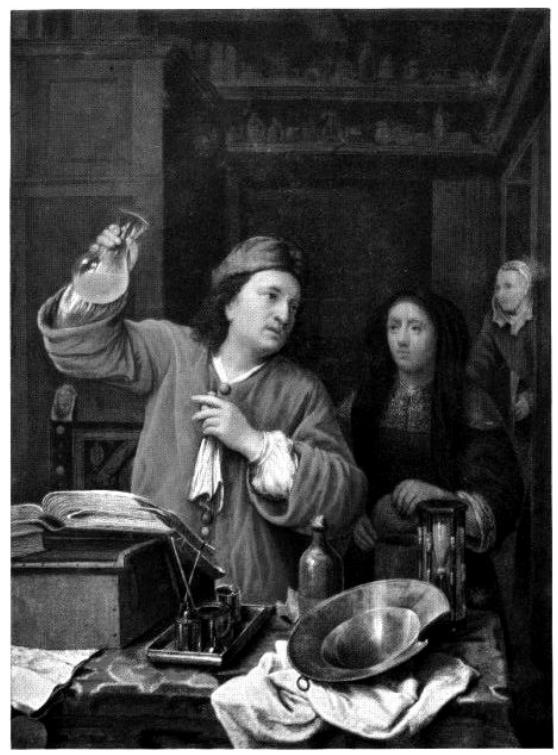

Konsultation

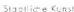

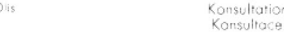

U erysipelu, puerperálni sopse a jinych streptokokovych infekci, colibacilbrnich infekci motových cest, lymphogranuloma inguinalo ou nestovic

\section{PRONTOSIL}

vynikoiici, dosud nepredstižený priprovek.

Prontosil püsobi daleko lépe, neĩ pozdbiji zavedene chemoteropeutikum. bity sulionomid, a ie znoćné lépe snósen.

Velmi dobłe osvédéén takè u operaci a porodù, u nichì ie nebezpeči infokce.

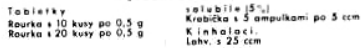

\section{GONOROE}

Ize dnes vyležiti v nékolika dnech orólnim uIfivónim noveho

$$
N E O-U L I R O N
$$

Rychie se resorbuje i vylučuje, takì mó neobyčeinè mohutný úcinek a pă tom se doble snási.

( $85^{\circ}$ a vice nea $95^{\circ}$ pii 2 . nórazu.

Úcinkuje léi u Zerstive koporky.

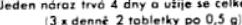

Povoernibalenit Rourka + 24 kuty po 0.5

$U$ lobarni pneumonie o bronchopneumonie. pneumokokové meningitidy, meningokokové meningitidy SULFAPYRIDIN "Bayer" Účnek Sulfopyridinu, namifreny proti preumokokorỳm infekcim,

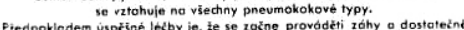
vysokými dóvkomi

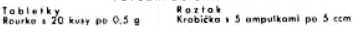

Fig. 7. Laflet Bayer. 


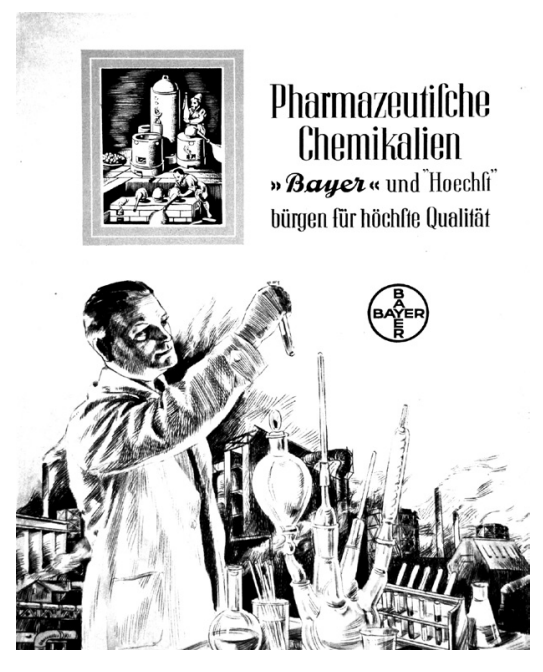

Price List 1938, CR.

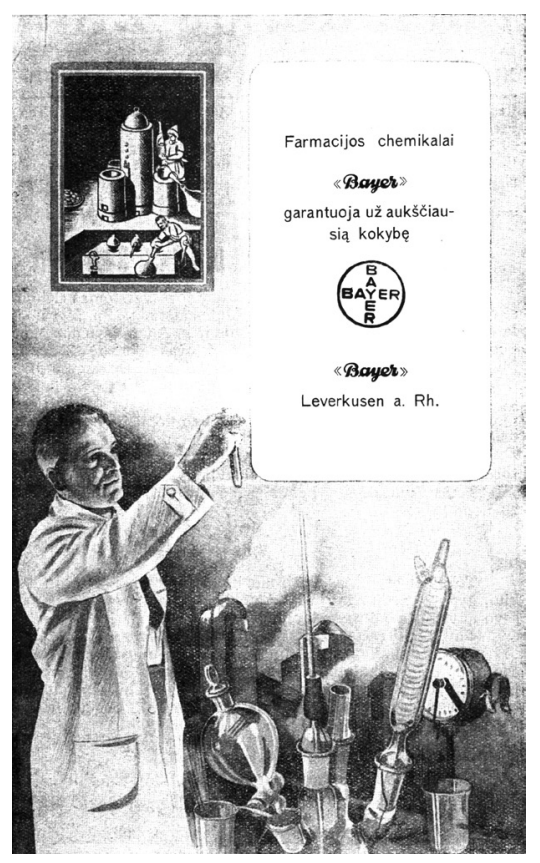

Farmacijosžinios, 1937.

Fig. 8. Advert. 
Gifts, sponsoring

Pharmaceutical companies distributed gifts and small presents among practitioners and pharmacists - diaries, thermometers, paperweights... Fig.9

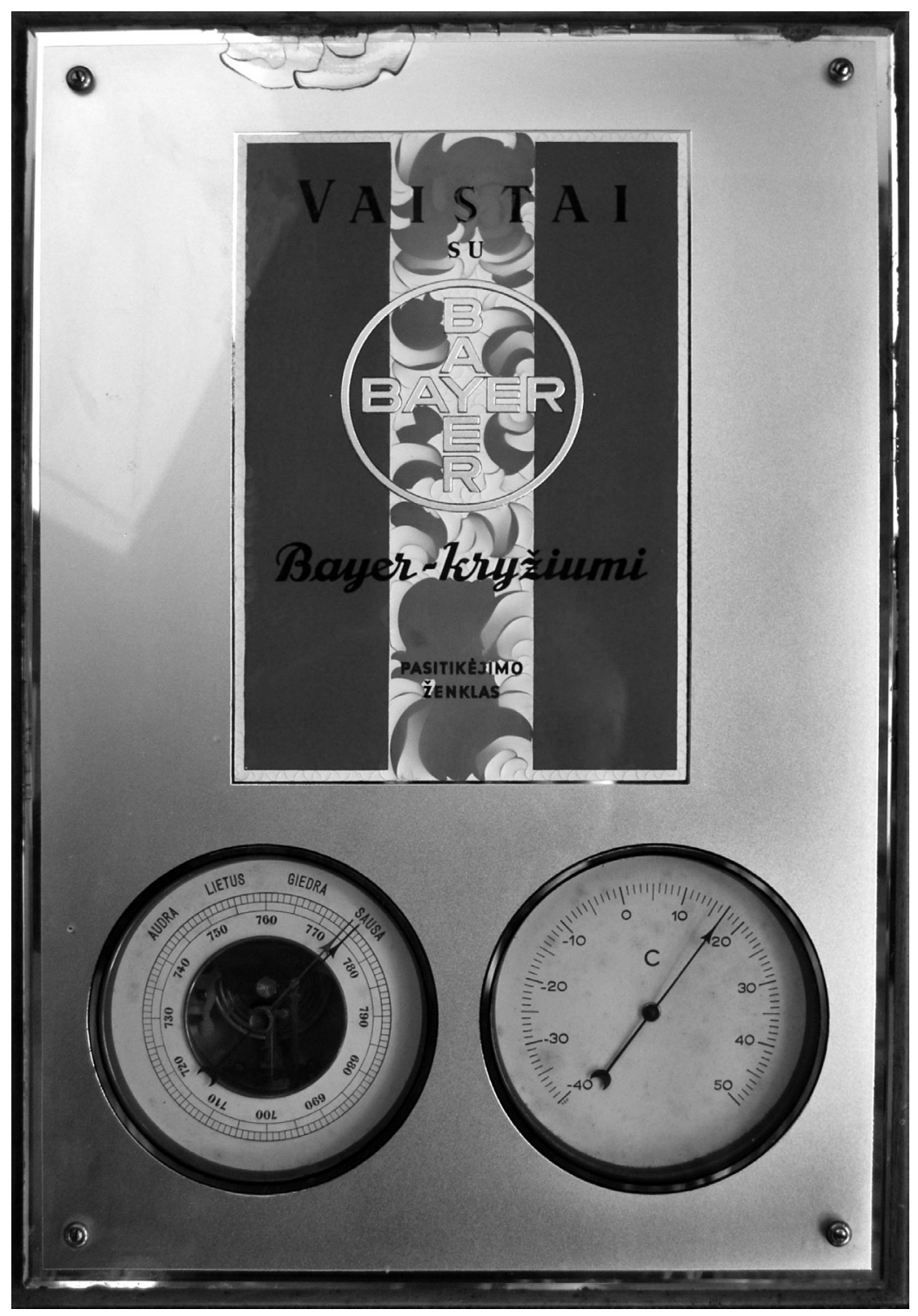

Fig. 9. Barometer. 


\section{Conclusion}

The Company Bayer had a unified marketing policy in both countries. Their international strategy was a matter of transnational corporation, as it is today.

Their promotional activities were almost the same in both countries, they differed mainly in quantity and intensity. Czechoslovakia as a significantly bigger and richer country was an important market for the company Bayer. The number of registered remedies and intensity of promotional activities correspond to this fact. Lithuania was smaller with developing industry and that is why Bayer used the German versions of their advertising materials and focused more on direct marketing activities.

Both countries developed their domestic pharmaceutical industry. In Czechoslovakia and Lithuania various campaigns, due to a strong nationalistic movement, were organized in order to encourage people to prefer domestic production. Lithuania paid great attention to the protection and development of domestic industry. This situation caused difficulties to foreign companies including Bayer that had to intensify its promotional activities.

Bayer advertising staff organized comparable advertisment campaign in both countries. This research will be carried on with the aim to include more countries.

\section{References}

${ }^{1}$ RUSEK, V.; DRÁBEK, P.; KUČEROVÁ, M.; HANZLÍČEK, Z. - Kapitoly z dějin Československé farmacie [Chapters from history of Czechoslovak Pharmacy]. 1st edition. Bratislava: Slovenské pedagogické nakladatelstvo Bratislava, 1970. p. $135-150$.

${ }^{2}$ DRÁBEK, P.; HANZLÍČEK, Z - "Farmacie ve dvacátém stoletî" [Pharmacy in 20th C.]. In Práce $z$ dějin techniky a prírodnich věd Sv. 6. Praha. ISSN 1801 - 0040. Řada: Česká technika na pozadí světového vývoje 3 (2005) 148 str.

${ }^{3}$ Havránek Hubert: Komentované zákony Československé Republiky. Československé zdravotnické zákony s príslušnými provádécimi predpisy. II. díl, část 1. Lékárnictví. Obchod lécivy a jedy. [Annotated Laws of the Czechoslovak Republic. Czechoslovak health care legislation with the relevant implementing regulations. II. part, part 1 Pharmacy. Pharmaceuticals and poisons trade.]. Praha: Československý kompas, 1938.

${ }^{4}$ LAUB, J.;HANUŠ, J. M. - Seznam lékárnických specialit povolených ku všeobecnému prodeji v Republice Československé do 15. listopadu 1924 [List of proprietary medicines allowed for sales in the Czechoslovak Republic until November 15 $\left.5^{\text {th }} 1924\right]$. Praha: Svaz Československého lékárnictva, tiskem V. Augusty v Litomyšli.

${ }^{5}$ Seznam lékárnických specialit povolených Ministerstvem veŕejného zdravotnictví a tělesné výchovy ku v̌̌eobecnému prodeji. Seznam obsahuje speciality, jež byly povoleny až do 31. března 1931 [List of proprietary medicines allowed by the Ministry of Public Health and Physical Education for sales. The list contains medicines allowed until March 31st 1931]. Praha: Státní tiskárna v Praze, 1931.

${ }^{6}$ Seznam lékárnických specialit povolených Ministerstvem verejného zdravotnictví a tèlesné výchovy ku všeobecnému prodeji. Seznam obsahuje speciality, jež byly povoleny až do 31. prosince 1934 [List of proprietary medicines allowed by the Ministry of Public Health and Physical Education for sales. The list contains medicines allowed until December 31st 1934]. Praha: Státní tiskárna v Praze, 1935.

${ }^{7}$ Doplněk k seznamu lékárnických specialit povolených Ministerstvem veŕejného zdravotnictví a tělesné výchovy ku všeobecnému prodeji. Doplněk obsahuje speciality, jež byly povoleny až do 31. prosince 1935 [Supplement to the list of proprietary medicines allowed by the Ministry of Public Health and Physical Education for sales. The supplement contains medicines allowed until December 31st 1935]. Praha: Státní tiskárna v Praze, 1936.

${ }^{8}$ Doplněk k seznamu lékárnických specialit povolených Ministerstvem veŕejného zdravotnictví a tělesné výchovy ku všeobecnému prodeji. Doplněk obsahuje speciality, jež byly povoleny až do 31. prosince 1936 [Supplement to the list of proprietary medicines allowed by the Ministry of Public Health and Physical Education for sales. The supplement contains medicines allowed until December 31st 1936]. Praha: Státní tiskárna v Praze, 1937. 
${ }^{9}$ Seznam lékárnických specialit povolených Ministerstvem veŕejného zdravotnictví a tělesné výchovy ku všeobecnému prodeji. Seznam obsahuje speciality, jež byly povoleny až do 31. prosince 1937 [List of proprietary medicines allowed by the Ministry of Public Health and Physical Education for sales. The list contains medicines allowed until December 31st 1937] Praha: Státní tiskárna v Praze, 1938.

${ }^{10}$ Doplněk k seznamu lékárnických specialit povolených $k$ všeobecnému prodeji Ministerstvem vnitra ke dni 28. unora 1942 [Supplement to the list of proprietary medicines allowed by the Ministry of Interior for sales until February 28th 1942]. Praha: Tiskárna Protektorátu Čechy a Morava, 1942.

${ }^{11}$ Sbirka zákonů a nařizení predepsaná nařizením ministerstva vnitra ze dne 27. května 1911 r. z. č. 103 [Collection of laws and regulations prescribed by Regulation of the Ministry of Interior from May 27 th 1911 No. 103 of Imperial Code]. Praha: Organizace českého lékárnictví pro Čechy, Moravu a Slezsko, Praha, 1911.

${ }^{12}$ Dossier A XVII 104 box No. 1278, Státní oblastní archiv Praha [State Regional Archive in Prague].

${ }^{13}$ KAIKARIS, A. - Lietuvos farmacijos istorija. Atsiminimai [History of Pharmacy in Lithuania. A Memoir]. Kaunas: Sveikatingumo ir medicinos reklamos centras, 2000. p. 50.

${ }^{14}$ ŽUKIEN, R. - "Lietuvos farmacija XX amžiuje" [Lithuanian pharmacy in the 20th century]. In Lietuvos farmacija [Lithuanian pharmacy]. Vilniaus: Lietuvos farmacijos sąjunga. Vol. 3, p. 185.

${ }^{15}$ Patentuotų ir dozuotų vaistų, leistų ir uždraustu ivežti i Lietuvą sąrašai : Medicinos Tarybos priimti 1926 $m$. gegužés mèn. 14 d., Vidaus reikalu ministerio patvirtinti $1926 \mathrm{~m}$. liepos mèn. $26 \mathrm{~d}$. [The list of patented medicines allowed for importing into Lithuania, approved by the Council of Medicine in 1926 May 14th Approved by Minister of the Interior in 1926 July 26th]. Kaunas: Sveikatos departamentas, 1927.

${ }^{16}$ Vaistu ivežimo iš užsienio taisyklès ir Patentuotų ir dozuotų vaistų, kuriuos leidžiama j̇vežti į Lietuvą, sąrašas [The rules of medicines import into Lithuania and list of patented medicines allowed for importing into Lithuania]. Kaunas: "Spindulio" b-vès spaust, 1928.

${ }^{17}$ Report of the Investigation of I. G. Farbenindustrie A. G. Available in WWW <URL:http://www. nonstopsystems.com/radio/article-IG-Farben-investigation-1945.pdf >. p. 65.

18 "Patentuotų ir dozuotų vaistų ịvežimo ị Lietuvą taisyklès" [The rules of medicines import into Lithuania]. Vyriausybès žinios [Government news]. N. 247 (1927) p. 4.

19 "Vaistų ịvežimo iš užsienio taisyklès" [The rules of medicines import]. Vyriausybès žinios [Government news]. N. ${ }^{o} 281$ (1928) p. 1-2.

${ }^{20}$ [I.G.Farbenindustrie Aktiengesellschaft, Casbis advertisement] in Medicina 1929, N. ${ }^{\circ}$ 5, p. 386.

${ }^{21}$ [Bayer advertisement]. N.o 7 (1936) p. 36.

${ }^{22}$ [Bayer advertisement]. N.o 4-5 (1939) p. 1.

${ }^{23}$ [Bayer advertisement]. N.o 10 (1937) p. 1.

${ }^{24}$ [Bayer advertisement]. N.o 12 (1938) p. 1. 